\title{
Donald Trump's Incendiary Rhetoric and Hate Speech in Tulsa, Oklahoma Rally on June 20, 2020 Put the United States on the Verge of Racial and Cultural Division
}

\author{
Aysar T. Yaseen ${ }^{1, *}$ \\ ${ }^{1}$ Faculty of Arts, The Arab American University, Palestine \\ *Correspondence: Faculty of Arts, Arab American University, P. O. Box 240 Jenin, Palestine. E-mail: \\ aysar.yaseen@aaup.edu
}

Received: September 28, $2020 \quad$ Accepted: December 6, 2020 Online Published: January 15, 2021

doi:10.5430/wjss.v8n1p81 URL: https://doi.org/10.5430/wjss.v8n1p81

\begin{abstract}
Anti-racial vilification legislations exist on a wide range and are supported by civil organizations as well as the two major political parties in the United States. As Public concerns about expressions of racial hatred exacerbated lately, racial derogatory comments and racial violence were evident in several areas in the U.S and became part of daily rhetoric. It seems that these legislations consolidated counterproductive effects and gave rise to racial differences rather than encrypting them. Furthermore, hate discourse was encumbered by the residue of long history of slavery and racial segregation. The American president who is supposed to be the role model for the common American man and woman failed to take the lead and proved to lack commands of leadership as well as initiatives of healing the nation in the midst of the present state of unrest and confusion. He has been abusive and having no commands of domestic policy. His discourse failed to live up to the expectations of the American people in suppressing racial and discriminatory remarks. On the contrary, he brags of being racist and bluntly uses hate expressions. In addition, he tries to systematize and institutionalize racism and discrimination. By using racist hate speech utterances as well as hate-speech acts, the president appears as a person with modest linguistic commands as his poor knowledge of illocutionary and perlocutionary effects of his utterances is prevalent. The analysis of Donald Trump's hate-speech-acts can be identified as raising validity claims which enact discrimination and support inequality in society.
\end{abstract}

Keywords: discrimination, rhetoric, hate discourse, racial language, vilification, Trump

\section{Introduction}

(Gelber, 2002) argues that a range of remedies may put to work to assist in resolution of racial complaints or offences. Among these are: apologies, a promise that such offence will not take place again, holding workshops and sessions at workplace to familiarize individuals and groups of racial vilification and how to avoid them and the consequences and the penalties of violators, implementing programs on how to eliminate discrimination and racial vilification, and broadcasting apologies and measures contradicting racially vilifying views. Trump seized all opportunities to make racial remarks and tried hardly to convince the public of their validity in society. Repeatedly, Trump showed no regret or remorse for uttering these discriminatory rhetoric publicly and on national TV stations. Why then president Trump is reluctant and shows a great deal of restraint to issue such an apology?

Is it power? Is it his poor linguistic commands? Is it his stubbornness? Is it his appreciation and love for dictatorship and authority? Is he aware that he became alienated even from some allies and supporters? Is he aware that he is risking winning a second term as a result of hate speech? Is he aware that the whole country in on the verge of division that is going to last for many decades to come as a result of his hate discourse? 


\section{Hate Speech}

The expression 'hate speech' acquires several definitions. First, it is defined as extreme and strong emotions in which subjective moods are involved, (Parekh, 2012),; second, it is simply perceived as purposeful disempowerment, (Perry, 2005); third, the term was simply used as is 'hate speech' to denote hatred in its emotional perspective, (Waldron, 2012a), and finally, (Weinstein \& Hare, 2009) defined hate speech as an expression which articulates hatred for another individual or group, usually based on a characteristic such as race which is perceived to be shared by members of the target group. Hate speech is banned to protect vulnerable racial, ethnic, religious, national, linguistic, sexual, or other subordinated or otherwise similarly situated minorities or groups. Ban normally is meant to prevent defamation which denotes reputationally detrimental communication to third parties of allegations about specifically identifiable individuals, which, on the preponderance of the evidence, can be called factually false, and have been made with inadequate care by the speaker as to the truthfulness of the alleged facts, (Nowak \& Rotunda, 2009). Banning certain actions or attitudes induced in hate speech preserves human dignity and thwarts violent actions as hateful expression within public discourse lead to harmful effects, such as violence or discrimination against target groups, and hateful expression within public discourse degrades its targets' inherent human dignity or equal citizenship. Nowadays, the expression is most likely used to express hatred in its subjective emotional sense.

\section{Hate-Speech-Acts}

Hate-speech-act or racist speech is an utterance which perpetrates, perpetuates and maintains discrimination. The effects of this discrimination on members of the victim groups include that they are silenced, in the sense that a response is rendered "unspeakable" (Langton, 1993:311). This entails the existence and or enactment of opposing policies that aim at appropriately uncovering and responding to this harm in the sense of giving equal opportunities and chances in the social domains. Furthermore, existing policies must be amended and revisited regularly to guarantee sustainability and conformity with newly surfaced social issues. Hate-speech-act is more than just offending people and hurting their feelings; discursively speaking, hate-speech-act gives prominence and circulation to hate discourse in society and eventually produces and reproduces racial discrimination and consolidates social inequalities which gives rise to legitimacy of such inequality against targeted groups. Fatal communal consequences such as discrimination, silencing, limitation on freedom, unequal opportunities, feeling of inferiority, and psychological harms become inevitable and part of everyday life practices. (Gelber, 2000a; 2000b; 1999) contends that It is important to note that the hate-speaker need not be identified or identifiable, nor need the hate-speaker be individually the subject of a response to the hate-speech-act. Response to hate-speech-act is unpredictable and may come in different shapes and reactions. Individuals and groups may respond to such acts differently and at diverse momentum depending on the hate-speaker's position and his role in society. In the scope of this research, the hate-speaker is identified as the commander-in chief who is supposed to be looked up to by all Americans as the role model for the whole country. He became, as an individual who represents the leadership, the subject of the response to the hate-speech-act, and the whole country came under a violent attack as the subject of a response to the hate-speech-act as well. The result is the alienation between the public and the leadership as well as street violence, looting, shooting, setting buildings on fire, blocking major streets and highways, setting police cars on fire, enmity and distrust between people and the police force, and so forth. Above all, laws and policies concerning vilification and discrimination become under scrutiny where reform of such laws becomes a need.

\section{Analysis}

Trump's hate speech utterances will be identified and analyzed in terms of the validity claims raised by the speaker and the identification of perlocutionary effects of the utterance on the targeted group(s). The analysis shows that hate-speech-acts can be identified as raising validity claims which enact discrimination and support inequality in societies.

Trump hopes to outshine media outlets and his opponents and to outrun the coronavirus pandemic as the country is heading for the 2020 election campaign. He sought to use the rally in Tulsa to bring momentum back to his campaign after coming under fire for his responses to the coronavirus and to the death of George Floyd. His campaign trail in Tulsa demonstrates just how difficult his endeavor is going to be, and the entire event was a mere controversy.

Trump's offensive start was so discouraging and embarrassing and was enough to tell a lot about the nature of his rhetoric trajectory of this campaign rally. He devoted more of his speech to hammering Democratic politicians, the protesters, and disputing the media coverage of his wobbly walk down a ramp at West Point earlier this month than to 
addressing the pandemic. He called the small crowd (the majority of them were whites and the blacks were protesters and not supporters) 'warriors' and all people outside are called 'bad people doing bad things' by Trump. The word 'warriors' entails positive characteristics among which are heroism, courage, and nationalism while the term 'bad people' denotes, among other things, cowardice, crime, looting, betrayal, treachery, and treason. Trump knows that the majority of people outside are people of color, and he meant to denigrate and vilify this ethnic group since it is historically been stereotyped as a group of high crime rate including murder, theft, looting, robbery and so forth.

Many believe that holding this rally in Tulsa in the midst of nationwide protests against the leadership's systemic racism is provocative in its sense. First, the speech was planned to take place on Juneteenth coinciding with the celebration of the end of slavery. The event was postponed intentionally in order not to take place at this important event (at least for back people) in history. It is planned to overshadow the black celebrations. Second, the rally was held at a walking distance from the site Tulsa Race Massacre that witnessed the bloodiest outbreaks of racist violence in which Greenwood black community was burned by white mobs on June 1, 1921. This is not a coincidence that both events took place in the same month. Trump's rally symbolizes a challenge and a threat to black community as it took place during this black peaceful and unarmed revolution as a spontaneous response to unjust treatment and systemic racism induced by the leadership, and the organizers are sending an embedded message to the black communities that you are going to face the same fate as those murdered in Tulsa Race Massacre if you continue your protests and tearing down statutes of political figures and leaders.

Protesters torn down Confederate statutes and memorials that are linked to slavery and the era of white supremacy. Trump accused those and called them the worst names by using powerful words such as 'mobs', and 'vandals', as if he is addressing enemies from different countries and calling the supporters to stop them from destroying history. Trump clearly declared in his speech that some protesters do not belong to the nation when he said: "Maybe some of them aren't even from our nation"; This is a clear evidence that some Americans are more Americans than others in reference to African Americans who participate heavily in the protests. He does not consider them Americans in a clear defense of slavery and its supporters and promoters. He said in this regards: "The unhinged left-wing mob is trying to vandalize our history, desecrating our monuments, our beautiful monuments, tear down our statues and punish, cancel and persecute anyone who does not conform to their demands for absolute and total control. We're not conforming."

Calling for a militaristic response against the peaceful and unarmed protesters along with his lack of empathy for the plight of the people of color and other racial groups in the United States demonstrate that Trump is not the president for all Americans and that he perceives some Americans as enemies who deserve to be destroyed by the use of excessive force and lethal weapons. "When you see those lunatics all over the streets, its damn nice to have arms," he said, vowing to protect Americans' rights to bear arms. "Our people are not nearly as violent, but if they ever were it would be a terrible, terrible day for the other side." When Trump calls his people "lunatics", he means that they do not fit in the street as protesters looking and asking for change to the better. He considers them mentally unstable and eventually, what they do is illegal, and their actions are irresponsible as they tend to destroy the country in his opinion. The word "lunatics" may also connotes that it is the responsibility of the military and the police to use excessive force against protesters to lock them in mental institutions since they constitute a threat to the other people "Trump's supporters" and the country. The word "lunatics" also connotes that these protesters are not acting out of their own free will, and that some outer forces whether domestic or foreign may induce them with hostile ideologies that might harm the country and its system. It is evident that Trump implies that these people are enemies who intend to destroy the country, and that there must be countermeasures by him and his supporters against these people. When Trump says: "its damn nice to have arms", it is a clear declaration that he is the president of his supporters only, and he considers the rest of the American people enemies and insurgents who deserve to be killed since having arms entails using them. It is a clear invitation for the use of power and weaponry against his unarmed people. He further claims that "supporters are our people", and they are good people since they are non-violent, and the rest of protesters are not our people since they represent the bad side "the other side" of the fight. His words are embedded with threat to the non-supporters when saying: "it is going to be terrible day for non-supporters if they do not conform and obey the leadership".

President Trump launched an attack on Joe Biden and the Democrats accusing them of taking the side of rioters and anarchists and encouraging them oust the incumbent leadership. Trump directly accused Joe Biden and his party of backing an army of "lunatics" whose main aim is to destroy him personally and the country's institutions as well. In a clear violation of all formal diplomacy, Trump turned against the Democratic nominee Joe Biden personally calling him names and picking on him. He called him 'sleepy Joe' Biden. On a different occasion, Trump claimed that "Biden is a very willing Trojan horse for socialism. When Biden first ran for president over 33 years ago, remember 
I used to call him $1 \%$ Joe, he never got more than $1 \%$ until Obama took him off the trash heap.", (see appendix). He further claimed "Biden blatantly copied the speech of a British politician, even ripping off the man's personal biography and family history and claiming it was his own. He forgot to say he was born in America. Joe Biden is a shameless hypocrite. Since 2003, he has delivered fawning eulogies to the funeral. And at those funerals of three leading supporters of segregation, including a former member of the KKK, and yet Biden is now smearing as racist, tens of millions of people like yourselves.", (see appendix). He further claimed "Joe Biden is not the leader of his party. Joe Biden is a helpless puppet of the radical left, and he's not radical left. I don't think he knows what he is anymore, but he was never radical left, but he's controlled by the radical left, and now he's really controlled.", and so forth, (see appendix). This is a sign of lack of knowledge in diplomacy as well as poor linguistic commands. Trump is unable to produce coherent texts where one topic is discussed. Because of this linguistic disability, observers notice that he keeps on changing topics, and on countless occurrences he invokes irrelevant topics that are out of the discussed topic framework. Trump's political and diplomatic lexicon is so deficient and shallow to the extent where he has to search for and struggle with appropriate words for the situation. His rhetoric is so deficient when it comes to expatiate upon politics, diplomacy, domestics and international policies. His only savior is to change the topic whenever he runs out of relevant lexis and to use a plethora of expressive language where his opponents are attacked at the personal level by the use of extraneous remarks. In his speech, unneeded attack was launched at Joe Biden and his son for example; Trump contends: "I told them. And look what happened to Biden in Ukraine where his son's paid $\$ 83,000$ a month. And he was jobless. Give me a break. $\$ 83,000$ a month. More than anybody. If Joe Biden were to become president an emboldened left, will launch a full scale assault on American life. You know that. They'll expel anyone who disagrees with them. Look what happens when you disagree. You use a term that's perfect and they're not happy with it. They call you a racist. They call you a horrible person. They want to crush religious liberty. They don't want religion. Silence religious believers, indoctrinate your children with hateful and vicious lies about our country, subsidize late term abortion and after birth execution.", (see appendix). Trump went further to accuse Biden of treason when he claimed in his speech that Biden took the side of China and other countries against his own country as stated in the following excerpts of his speech: "On one of the single most important policy decisions of our lifetime, Joe Biden sided with China over America.", "Joe Biden opposed killing Qasem Soleimani”, "Biden is a puppet for China", "Biden is a very willing Trojan horse for socialism". On top, Trump accused Biden of racism and discrimination as in the following excerpts from his speech: "Sleepy Joe. A man who praised and partnered with segregationists, shift millions of black American jobs overseas", "Biden hollowed out our middle class, including our black middle class with open borders", "Virtually every policy that has hurt black Americans for half a century, Joe Biden has supported or enacted", and so forth, (see appendix). It is patently obvious that Trump's paucity of knowledge in countless fields, politics and diplomacy in particular, makes him so offensive where we find him attack people personally as well as people's personalities such as making effusive remarks or propagating false beliefs thinking that might save the situation. These imprudent decisions propel into propensity for more violence and anarchy.

Trump's attack on Biden's personality (sleepy Joe), Biden's old achievements and history (running for presidency 30 years ago), his linguistic ability (a comment from Joe Biden," but he didn't say it. Professional people, great students in English lit, people that are very smart say it. Joe Biden said, and they'll go into this highly complex paragraph, beautifully worded and I say, "Joe didn't say that. Joe doesn't even understand it."), (see appendix), and his son (the Ukraine story) is a sign of weakness in the sense that Trump is unaware of the situation the country goes through. It is a sign of miscalculation where Trump thinks that it is always the time to attack his political opponents and Democratic nominee for the upcoming November elections. He forgets that this rally comes in the midst of grave crossroads for the country as a whole. Trumps ignored the main theme of the rally which is supposed to be putting the country together again and addressing the present dilemmas, namely, the pandemic and the staggering racial disparities. Trump totally ignores this chance for reconciliation and focused on trivial and personal issues of his political opponents. He only gave prominence to issues that resonate with his mission to control and dominate and to expand his dynasty of dictatorship.

On many occasions Trump finds refuge in self-laudatory remarks when his lexis get to a dead lock. He claimed on many instances that his personal response to the coronavirus pandemic has save hundreds of thousands of American lives. On another occasion Trump warned that, unless he was re-elected, all Americans would endure the "chaos you're seeing in our Democratic-run cities." In his speech, he postulates: "and because of the Chinese virus, what happened about three months ago, it looked like we were in big trouble and we were, and I got it back together." He further stresses his personal efforts in combating the virus when saying: "I have done a phenomenal job with it, I shut down the United States to very heavily infected but all people from China in late January, which is months earlier 
than other people would have done it, if they would have done it at all.", (see appendix). On other occasions he showed how egocentric and narcissistic he is; he contends that, "If I lose an election over that, you know what? This country is in big trouble", "So I guess I am right", "I've done more for the black community in four years than Joe Biden has done in 47 years", "We slashed regulations and passed massive tax cuts to give black workers a pay raise like they've never, ever gotten before and lift up black owned businesses", and so forth, (see appendix).

It was claimed by Trump's supporters that large number of people were turned away, but it was evident that whole sections of the arena were empty. Trump and his allies blamed continuous warnings by health experts regarding social and physical distancing, radical protesters, and the media for the disappointing turnout of the crowd which was supposed to constitute a good start for the brutally hurt political leadership. Still this narcissistic president dreaming of reelection viewed Tulsa rally as anew encouraging start as well as a turning point in his political agenda.

Trump blamed the media for discouraging attendees. The media was under Trump's attack when reported that there were some shouting matches and scuffles outside the event between around 30 Black Lives Matter demonstrators and some Trump supporters waiting to enter. One reporter added that he saw no sign any Trump supporters were prevented from entering the arena or overflow area.

Trump is so sensitive to media reports as he perceives these media outlets as opponents to his leadership. These outlets, in his opinion, seize every possible opportunity to portray him as incompetent president and expose his mishaps to the public. Trump vilified reporters and TV stations publicly on many occasions. He openly accused them of lying, being unprofessional, and as being bad reporters. In his speech, Trump accused the media of undermining him as he claimed, "Not one media group said I made a good speech or I made a great speech.", "And then when I say the looters, the anarchists, the agitators, they say, "What a terrible thing for our president to say, what a terrible thing.", (see appendix). In his speech, Trump accused the media of taking the protesters' side and calling them "lovely people"; in this regards, he postulates, "You listen to the fake news, they say, "Oh, the protesters were lovely."

He used the speech-act of threat when he threatens that his supporters are going to take over institutions and opposing groups in a clear insinuation of a coup d'etat. Trump mentioned his intentions on many occasions when he raised the slogan of being the president for ever. He might be planning for seizure of power by a military coup at the end of his term.

He used his discriminatory remarks against China where diplomacy must be preserved. He called the virus again 'China virus' where many believe that he meant Chinese people and Chinese leaders are viruses themselves. The he used the derogatory term 'kung flu' in direct disrespect and humiliation of Chinese heritage and traditions.

His lies kept on circulating during the speech in Tulsa rally. He claimed that he has done a phenomenal job in combating and mitigation the virus while downplaying the effect of it on the American people. He further claimed that he himself saved hundreds of thousands of lives. In addition to the lies and hyperboles, he stressed the use of the first person singular pronoun 'I' as a sign of arrogance, supremacy, and power where he attributes all efforts, achievement, and successes to himself personally in a clear way of negligence and dishonesty.

Trump's speech is characterized of being simple when it comes to vocabulary, built on repetition which is considered by many linguists as a bad style in English, sudden topic switching to distract listener and lose following up and interest by the listener, and most importantly, the use of dysphemism and hyperboles to either exaggerate the bad qualities of his opponents or to introduce claims that lack evidence, i.e. pure lies. Trump lacks knowledge on how to speak topically or at least speak on a topic where he must limit himself to the topic framework. Furthermore, he is unpredictable when it comes to the invoked topic. This is something you do not expect from the president who addresses public and decisive issues that are crucial to the whole country. Yes we can expect this from any speaker whom we encounter on daily basis but not the president of the United States. The use of simple vocabulary and syntactic structures is an indication of his poor repertoire in general and his lack of knowledge of political terminology in particular; the switch in topic takes place whenever he runs out of words, and this happens repeatedly and quickly. Repetition of phrases such as 'I've never seen anything like it', 'that's the word', 'they're great', 'it's happening', and hedges and fillers such as 'huh', 'okay', 'oh good', 'by the way', 'nope', 'well', etc. is an indication of hesitation and that he is buying time to figure out what to say next.

As a president of all Americans, Trump must have dedicated the larger portion of his speech to address black people as they are the ones who suffer most from police brutality and their excessive use of power. Black community has just lost several innocent unarmed people due to unjust treatment by the leadership. The latest was the Murder of George Floyd which instigated nationwide protests against the police departments and their apparatuses. Theses 
protests insinuated directly and indirectly the racial inequality in the American society. The president failed in his speech to show tacit or direct support to the nationwide calls for equality. On the contrary, he gave tacit approval for the staggering racial disparities and inequalities in almost all parts of his speech. For example, he called protesters, the majority of whom are black people, looters, anarchists, and agitators. Furthermore, Trump called these people left-wing mobs, people carrying out brutal assault on our nation and its values. The word "protesters" was mentioned only twice in Trump's speech, and when he mentioned the word, he was so sarcastic and accused them of being anarchists and armed people who intend to take over cities and destroy businesses; he said in this regards: "Now these are anarchists, these are not protestors. You listen to the fake news, they say, "Oh, the protesters were lovely." Could you imagine if people just even slightly to the right tried to take over Seattle? They'd have machine guns out to get them, but these people can take over the city, look at what they've done to businesspeople that have spent years and years building their business, and now they're wiped out", (see appendix). These discriminatory and vilifying remarks intend to downplay and mitigate the supreme and the humanitarian goals of the protests and the demands of the protesters. Trump intentionally avoided the use of the terms "protesters" and "protests" in his speech to downgrade, belittle, and undermine the protests, the protesters and their demands and vilify and discriminate against demonstrators as the majority of these protesters is black people. In order to degrade and empty them of their value and importance, these protests were called names by Trump such as "brutal assault on our nation and the values of our nation" and protesters were called "maniacs", "rioters", "arsonists", "leftists", and "crazy people" who are going to exert and evince violence and mayhem in the country. Intentionally, Trump failed to mention George Floyd's killing by the white police; he failed to mention the victim's name and/or any of his family members and their grieve or their hefty loss in such heinous way. He overlooked the long history of police brutality against people of color in the United States, and he did not address the issue in the speech.

Trump totally avoided using other words that are relevant and closely related to the status quo. George Floyd was never mentioned in his speech. This shows how careless the president is and that the killing of a black person by a white policeman does not even worth mentioning in his speech. This is a sign of discrimination, and that the black lives do not matter. Many think that if the situation was the other way around where the victim is a white person, the president will give the story space and time in his speech, and he will call the killer all kinds of names in addition to showing empathy for the victim and his family. The term 'black people' or 'black Americans' was not used in relation to the current situation in Trump's speech. The term was mentioned seven times only throughout the speech. It was used either to lash out at his critics and political opponents and to falsely claim that black people are victims of Joe Biden's policies as in, 'Sleepy Joe. A man who praised and partnered with segregationists, shift millions of black American jobs overseas', and 'Virtually every policy that has hurt black Americans for half a century, Joe Biden has supported or enacted' or to brag to his audience and make laudatory remarks about achievements he has never done such as 'I've done more for the black community in four years than Joe Biden has done in 47 years', and 'I recently signed groundbreaking criminal justice reform. I secured record and permanent funding for historically black colleges and universities. We slashed regulations and passed massive tax cuts to give black workers a pay raise like they've never, ever gotten before and lift up black owned businesses', (see appendix). The words 'demonstrators' and 'demonstrations' were not used by Trump in his speech. Both words have positive connotations where demonstrators normally revolt against inequalities and suppression by authoritarian leadership. Trump strategically used the words 'rioters', 'riot', and 'rioting' instead of demonstrators to indicate illegality of the whole situation. The word 'rioters' was used four times in his speech. This rhetorical use was meant to equate demonstrators with vandals, and that their demands are illegal, and their actions are violations of law and order. Describing demonstrators as rioters is meant to gain the public support against protesters and their legal demands. The word 'rioters' denotes vandalism, looting, burning down buildings, threatening of peaceful citizens, and so forth. This usage also gives the permission for the police and other governmental apparatuses to use force and sometimes excessive force against demonstrators as they are perceived as a threat to the country and the peaceful citizens by the head of the state.

Trump's speech is loaded with the use of the first person singular pronoun 'I' and plural pronoun 'we' in addition to the possessive pronoun 'our' in an attempt to express superiority, power, unity and solidarity. The first person singular pronoun 'I' is used 297 times. 'We' is used 190 times throughout his speech while the possessive pronoun 'our' is used on 87 instances. These pronouns were also used to counterpart the third person plural pronoun 'they' and 'them' which are used 214 times and 48 times respectively in Trump's speech, and the possessive pronoun 'their' is used 22 times. This intensive usage of pronouns ('we'/'they' dichotomy) is a clear indication of division, fragmentation and enmity. 
The personal pronoun is a grammatical form, a subcategory of the pronoun class, which itself represents a subcategory of noun. Personal pronouns function as the heads of pronoun phrases or noun phrases. They are words that take the place of common and proper nouns, (Huddleston, 1984). The use of the pronoun 'I' and the inclusive pronoun 'we' outnumbered the use of any other pronouns throughout his speech. Trump tends to hail himself for every single positive act and achievement and consider them his own. He used the first person pronoun 'I' 297 times, and this usage outnumbered the use of any other pronoun. This is an indication of arrogance and selfishness where president Trump sees himself as better and more important than his people. Trump even favors himself over his supporters. Furthermore, the use of the third person plural pronoun 'they' is purposefully used to serve Trump's agenda. In countless occasions, the pronoun was always followed by a negative description of a characteristic or an action done by the "other", i.e. Trump's opponents where he meant everyone who opposes him. The "they" were always portrayed as villains and evil whose purpose is to destroy and jeopardize the country. For example, he elaborated phrases such as "They want to demolish our heritage", "they can impose their new oppressive regime in its place", "They want to defund and dissolve our police departments", "They were doing bad things", "They got a lot of problems", "they were the arsonists", "They don't want me", "Joe Biden and the Democrats want to prosecute Americans for going to church, but not for burning a church. They believe you can riot, vandalize and destroy", and so forth. This purposeful usage consolidates the deep gap and the alienation between the public and its leadership. Trump sees in himself the undefeated candidate whether with or without the support of the people. He gives prominence to himself by focusing on the use of the first person singular pronoun while looking down on people. Trump tends to detach himself from the public when stressing the importance of the 'one leader' or 'one party' strategy and way of governance.

Table 1. Frequency of the Use of Personal Pronouns

\begin{tabular}{ll}
\hline Personal pronoun & Frequency of usage \\
\hline First person singular pronoun 'I' & 297 \\
First person singular pronoun 'me' & 22 \\
First person plural pronoun 'we' & 190 \\
First person plural pronoun 'us' & 12 \\
Second person pronoun 'you' & 203 \\
Second person pronoun 'your' & --- \\
Third person singular pronoun 'he' & 68 \\
Third person singular pronoun 'him' & 13 \\
Third person singular pronoun 'she' & 12 \\
Third person singular pronoun 'her' & 3 \\
Third person plural 'they' & 214 \\
Third person plural 'them' & 48 \\
\hline
\end{tabular}

As for possessive pronouns, they are pronouns that express possession or some other relationship to another word or phrase and can perform five functions in clauses: subject, subject complement, direct object, indirect object, and prepositional complement. Moreover, the possessive pronoun is a subcategory of pronoun class which in its turn is a subcategory of the noun. Possessive pronouns function as the heads of pronoun phrases or noun phrases, (Brinton, 2000). The use of possessive pronouns 'our' (Trump is included) and 'your' (used to address his supporters) outnumbered the use of the possessive pronoun 'their'. Both pronouns 'our' and 'your' are used favorably to indicate unity and solidarity as in, 'our people and our nation', 'our police forces', 'our great farmers', 'our most distinguished republican leaders', 'our country' or to indicate achievements and values to surmise victory and success as in, 'your devotion', 'your two great senators and governor in Oklahoma', 'your congressman who I am going to introduce', 'your 401 (k)s are doing very well', and so forth. Trump used the possessive pronoun 'their' to discriminate against his political rivals and the people protesting against inequalities and police brutality and excessive use of force against them in the streets; it is used to deepen the political and racial and cultural gap and division in the U.S. In almost all instances in his speech, Trump used the possessive pronoun 'their' that forms the head of a noun phrase to describe negative actions or deeds of his opponents such as 'you never hear them saying, they're not wearing their mask', 'You don't hear their say, as they're breaking windows and running in', 'They want to demolish our heritage so they can impose their new oppressive regime in its place', 'I know our people, but we will never submit to their threats and we will never let them destroy our nation', and so forth. 
Table 2. Frequency of the Use of Possessive Pronouns

\begin{tabular}{ll}
\hline Possessive pronoun & Frequency of usage \\
\hline 'me' & 22 \\
'mine' & 3 \\
'Our' & 87 \\
'ours' & --- \\
'your' & 47 \\
'Yours' & --- \\
'His' & 15 \\
'her' \& 'hers' & 2 \\
'its' & 1 \\
'Their' & 21 \\
'theirs' & --- \\
\hline
\end{tabular}

\section{Conclusion}

Expressing admiration of the slogan "white power" and retweeting it is totally unacceptable as it is inappropriate. Vilifying language used by the president is not as the same one used by the common man and woman. It becomes part of the country's institutions where systemic and institutional racism and discrimination become vexed issue. On countless occasions president Trump showed no respect to his multiracial society. On the contrary, his extraneous rhetoric is loaded with discriminatory remarks where people of color in America were dehumanized and mistreated. A torrent of criticism for Trump's racial rhetoric and police brutality received no attention from the leadership. This gave rise to the idea that racial disparities are not transient in the United States; on the contrary, they are deeply rooted and entrenched in the American society and unlikely to disappear in the foreseeable future. It seems that racial equality is a farfetched endeavor as the leadership is turning a blind eye to the nationwide racial protests.

Trump's recalcitrant attitude and his refusal to ask for directions along with his shallow political and domestic policy lexicon made him lag behind his opponents. In his speech, nothing is said to uplift the country and the morale of the people. The speech was wholly dedicated to lash out at his critics and opponents in an angry way. Trump stuck to his guns throughout his speech. Instead of trying to save what is left of hope to put the country back on track again, Trump added insult to injury when blaming all wrong doings on others (Biden, protesters, China, the virus, etc.). He Blamed others for his deficiencies of all sorts (linguistic, rhetorical, political, diplomatic and social). He verbally attacked and bullied everyone who does not resonate with his mission. His staggering racial remarks put the whole country in limbo. Among the perlocutionary effects of Trump's utterances are lack of nationalistic feelings, hate and hate crimes, nonbelonging, violence, hostility, stereotyping and labeling, rise of anti-society movements, rise of anti-language, ethnocentrism, and discrimination.

Trump's lack of leadership regarding racial division proved that he is not a war-time leader whether the war against the pandemic or the racial disparities. Many believe that there is no hope that the president will come up with a national plan to curb down the spike of the nationwide uprising against racial discrimination. As a result, burgeoning demands for his resignation will soon become evident. Trump's ongoing stunts backfired on him and his leadership, and Tulsa rally is the first clear indication that Trump is politically finished.

Using racial language, hate terminology, and excessive use of antonyms such as 'bad' and 'warriors or good', 'left' and 'right', 'black Americans or African Americans' and 'white', 'we' and 'they', and so forth is a clear indication of the rise of hate speech an division in the United States. As this language is used by the president, it indicates that systemic institutional racism and discrimination extort the unity of the country. It consolidates the perplexity of the staggering racial disparities, and that the whole country is marred by exultant, short-tempered, vulgar, narcissist, and authoritarian president whose main goal is simply hijacking presidency and winning a second term. American people now know the kind of president they have; he is a president stuck to his guns throughout the crisis; a president who does not want to listen; a president who is willing to violate and change the rules to the advantage of his leadership.

As a result of Trump's racism and hate rhetoric, American people are fully aware that Trump constitutes a threat to the Americans as well as their institutions and their unity. Eventually, lack of faith in the system is spreading. Furthermore, he has been abusive to allies leaders and has no commands of foreign policies. The United States has suffered grievously in terms of foreign allies, and its image was tarnished by Trump's racism and hostility. As a 
result, the whole country is in dismay; and democracy is under assault by the leadership. Recently, burgeoning demands for Trump to resign are on the rise.

Anti-vilifications and anti-discriminations laws and legislations must be abolished completely from the legislative systems of the United States since their existence connotes inequality and that black people are second-hand citizens. The existence of such laws and legislations and the existence of litigations permitted by the court indicate that white supremacy did exist and is going to last forever. For example, the existence of hate-speech laws implies the existence of hate speech in society, and the existence of anti-vilification and anti-discrimination laws gives the implication that vilification and discrimination exist, and that these laws are there to respond to harms and damages resulted from such offences. If the U.S. is one united country, and its citizens are equal in the eye of law and have equal rights, then there is no need for such anti-vilification and anti-discrimination laws to exist because this existence denotes division and fragmentation. Their existence in the first place only means that inequality does exist, and these laws are there to keep law and order. In other words, their existence is harmful to the country and its legal system. Does China for example have such laws at the same scale as in the United States or does it have the same number of litigants in vilification cases? Does Japan have such laws at the same scale as in the U.S. or have the same number of litigants in discrimination cases? The answer is simply, No. All in all, the existence of such laws is counter-productive and deepens racial differences rather than obliterates them.

\section{References}

Brinton, L. J. (2000). The Structure of Modern English: A Linguistic Introduction. Amsterdam/Philadelphia: John Benjamins Publishing Co. https://doi.org/10.1075/z.94

Gelber, K. (1999). Treaties and Intergovernmental Relations in Australia: Political Implications of the Toonen Case. Australian Journal of Politics and History, 45(3), 330-346. https://doi.org/10.1111/1467-8497.00068

Gelber, K. (2000a). Implementing Racial Anti-Vilification Laws in New South Wales 1989 to 1998: A Study. Australian Journal of Public Administration, 59(1), 13-23. https://doi.org/10.1111/1467-8500.t01-1-00136

Gelber, K. (2000b). Hate Crimes: Public Policy Implications of the Inclusion of Gender. Australian Journal of Political Science, 35(2), 275-289. https://doi.org/10.1080/713649322

Gelber, K. (2002). Speaking Back: The free speech versus hate speech debate. Amsterdam \& Philadelphia: John Benjamins Publishing Co. https://doi.org/10.1075/dapsac.1

Langton, R. (1993). Speech Acts and Unspeakable Acts. Philosophy and Public Affairs, 22(4), 293-330.

Nowak, J. E., \& Rotunda, R. D. (2009). Constitutional Law (8th ed.). St. Paul, Minnesota: West.

Parekh, B. (2012). 'Is There a Case for Banning Hate Speech?' In M. Herz, \& P. Molnar (Eds.), The Content and Context of Hate Speech: Rethinking Regulation and Responses (37-56). Cambridge: Cambridge University Press. https://doi.org/10.1017/CBO9781139042871.006

Perry, B. (2005). A Crime By Any Other Name: The Semantics of Hate. Journal of Hate Studies, 4(1), 121-37. https://doi.org/10.33972/jhs.35

Waldron, J. (2012a). The Harm in Hate Speech. Boston, MA: Harvard University Press. https://doi.org/10.4159/harvard.9780674065086

Weinstein, J., \& Hare, I. (2009). 'General Introduction'. In I. Hare, \& J. Weinstein (Eds.), Extreme Speech and Democracy (pp. 1-7). Oxford: Oxford University https://doi.org/10.1093/acprof:oso/9780199548781.003.0001

\section{Appendix}

\section{Full text of Trump's speech in Tulsa, Oklahoma}

\section{Donald Trump: (01:11)}

Thank you, thank you. So we begin, Oklahoma, we begin. Thank you, Oklahoma. And thank you to Vice President Mike Pence. We begin, we begin our campaign. Thank you. We begin our campaign and I just want to thank all of you, you are warriors. I've been watching the fake news for weeks now, and everything is negative. Don't go, don't come, don't do anything. Today it was like, I've never seen anything like it. I've never seen anything like it. You are warriors, thank you. We had some very bad people outside. We had some very bad people outside, they were doing 
bad things. But I really do, I appreciate it. We have just a tremendous group of people in Oklahoma. And I hear, I hear from your two great Senators and your governor that we're doing very well in Oklahoma, that's the word. That's the word. I stand before you today to declare the silent majority is stronger than ever before. Five months from now, we're going to defeat sleepy Joe Biden. Boy, does he get a pass from these people, huh? We're going to stop the radical left. We're going to build a future of safety and opportunity for Americans of every race, color, religion, and creed. Republicans are the party of liberty, equality, and justice for all. We are the party of Abraham Lincoln and we are the party of law and order. Think of what we've done. We will have close to 300 federal judges appointed and approved by the end of my first time, that's an all time record. That's an all time record. I've always heard how important judges are. Now we know how important they are. Think of that over 300, around 300, by the end of the term. And when we have another four years, we're going to have a big, big percentage of the total number. Very important, November 3rd.

Donald Trump: (04:26)

And two great Supreme Court judges. So we have two justices of the Supreme Court, Justice Gorsuch, Justice Kavanaugh, they're great. They are, they're great. We have two. And we could get a few more, yeah, we can get a few more. We've spent over $\$ 2$ trillion to completely rebuild the unmatched strength and power of the United States Military. And all of that incredible equipment, whether it's submarines or missiles or rockets or jet fighters, bombers, it's all built in the USA. We passed V.A. Choice. Thank you very much, Jim. Where's my Senator? Jim Inhofe, you better vote for him, he's running, he's great.

\section{Donald Trump: (05:39)}

But we'll get to him and James Lankford in a second, two great Senators. You have two great senators. So we passed V.A. Choice. So if you're a veteran, for years and years, they've wanted to do it for almost 50 years, we got it done. We get a lot of things done. And so if you're a veteran and you have to wait on line for one week, two weeks, three weeks, five weeks, seven weeks, two months. What happens is you go outside, you get a private doctor, you get fixed up and they pay your bill. We take care of the bill. We take care of the bill and you get immediate service. It's never happened before. And our approval rating at the V.A. is now 91\%, that's how good it is. Never been anywhere near that number. Never been anywhere near that number.

Donald Trump: (06:45)

And V.A. accountability, we had a lot of bad people in the V.A. People that didn't love our vets, people that were sadistic, people that stole, a lot of bad people. You couldn't get rid of them because they were, let's say it could be unions, it could be civil service, right, let's say, let's just say. And so you couldn't get it done. That was another one for decades and decades, they wanted to get it changed. And I got it done with those people and your Congressman, your Congressman who I'm going to introduce. V.A. accountability, and now somebody treats our veterans badly and we look at them and what do we say? We say, you're fired, get out, right? Get out.

Donald Trump: (07:37)

They got rid of a lot of bad people that were there for a long time. Sort of like me in Washington, draining the swamp. I never knew it was so deep. But it's happening. It's happening, I never knew it was so deep. It's deep and thick and a lot of bad characters. Thank you. We're lowering the price of prescription drugs, making our allies pay their fair share. They get a big bargain on drug prices and enacting fair trade deals. That finally, finally, after all these years put America first. I've been saying it for a long time. We passed the largest tax cuts in the history of our country. The Democrats want to raise your taxes. Tell me about that. Tell me about that. I guess I'm old fashioned. All my life, all my life, I heard politicians want to lower taxes, not raise them. If you could lower him, you couldn't lose. The Democrats want to substantially raise your taxes. How do you figure that? How do you figure that? And regulation cuts, we passed more regulation cuts than any administration in the history of our country. And with the help of our great energy workers, many of them come from the great state of Oklahoma. Do you ever notice that Biden, no, do you ever notice that Biden oftentimes gets the state wrong? He's in Iowa and he says it's good to be in Idaho. No, no, you're in Iowa. He's in New Hampshire and he says it's great to be in Ohio. No, no, no, you're in New Hampshire. That happens to him all the time, hasn't happened to me yet. When that happens, there's nothing you can do to make up for it. You might as well just walk off the stage because the speech is a disaster. Right, right. But we just turned the United States into the dominant energy super power of the world, of the world. And because of the Chinese virus, what happened about three months ago, it looked like we were in big trouble and we were, and I got it back together. I called Russia. Right, I called Russia.

Donald Trump: (10:27) 
I called Saudi Arabia and believe it or not, I called Mexico. Mexico was a little bit tough. That's called OPEC Plus, did you ever hear of OPEC Plus. That's OPEC Plus plus. And we got them to do the right thing and we have our energy back to almost $\$ 40$ a barrel, meaning you have an energy business again. Almost $\$ 40$ a barrel. Couple of months ago, it was zero and we were going to lose 10 million energy jobs, 10 million jobs. So Texas and Oklahoma and North Dakota, and many other states would have been hurt. Now you think you're going to be hurt there. You try putting AOC in judge of your energy. That will make the pandemic look like child's play to the people in energy. She has one problem, it's called petroleum. No president or administration has done more in the first three and a half years than the Trump administration. Not even close. Nobody.

Donald Trump: (11:39)

Our incredible success in rebuilding America stands in stark contrast to the extremism and destruction and violence of the radical left. We just saw it outside. We just saw it outside, you saw these thugs that came along. These people, call them protesters, isn't it beautiful, it's so beautiful. No, they're so wonderful. They call them the Boston Tea Party. They're so wonderful. Yeah, they call them ... You ever watch fake news, CNN, you ever watch? [inaudible 00:12:16]

Donald Trump: (12:20)

How about the CNN anchor, how about the CNN anchor, you know, did a little shave job in the head, which is fine. And he's standing in front of a building saying, "things are very peaceful here." And the building is, it looks like the biggest fire I've ever seen. The whole town is burning. It's like the biggest fire. And he said, "Things are very good here, Anderson. I think it's great. These are wonderful people, Anderson." Did you ever see that? It looked like the world was coming to an end. And we did something in Minneapolis after watching for three or four days, I called, I said, "You got to get ... you can't protect yourselves." I got them to take 8,000 National Guardsmen. And in one hour it all ended and they rode through the next three weeks with no problem.

Donald Trump: (13:28)

And we did the same thing in other cities. But how about Seattle? Isn't that great? So they take over a big chunk of a city called Seattle. I mean, we're not talking about some little place, we're talking about Seattle. Have you ever been to Seattle? They took over a big chunk and the governor, who's radical left, all of these places I talk about are Democrat, you know that, every one of them, every one of them. And I'd have an offer out, I said, "Anytime you want we'll come in, we'll straighten it out in one hour or less." Now I may be wrong, but it's probably better for us to just watch that disaster.

Donald Trump: (14:28)

I flew in with some of our great congressmen, who we're going to introduce it a second. And I said to them, "Congressmen, what do you think? I can straighten it out fast, should we just go in? No, sir. Let it simmer for a little while. Let people see what radical left Democrats will do to our country." But Americans have watched left wing radicals, burn down buildings, loot businesses, destroy private property, injure hundreds of dedicated police offices. These police officers, they get injured, they don't complain. They're incredible. And injure thousands upon thousands of people only to hear the radical fake news say what a beautiful rally it was. And they never talk about COVID. They don't talk about, when you see 25,000 people walking down Fifth Avenue or walking down a street of a Democrat run city, you never hear them saying, they're not wearing their mask. You don't hear their say, as they're breaking windows and running in. And then when I say the looters, the anarchists, the agitators, they say, "What a terrible thing for our president to say, what a terrible thing."

Donald Trump: (16:08)

But you don't hear them talking about COVID, COVID, to be specific, COVID-19. That name gets further and further away from China, as opposed to calling it the Chinese virus. And despite the fact that we ... I have done a phenomenal job with it, I shut down the United States to very heavily infected but all people from China in late January, which is months earlier than other people would have done it, if they would have done it at all. I saved hundreds of thousands of lives. We don't ever get even a mention. Then I closed it down to Europe early, closed it down because I saw what was happening. And by the way, most people said, don't do it, don't do it. We saved hundreds of thousands of lives and all we do is get hit on like we're terrible. And what we've done with the ventilators and with the medical equipment. And with testing, you know, testing is a double edged sword. We've tested now 25 million people. It's probably 20 million people more than anybody else. Germany's done a lot. South Korea has done a lot.

Donald Trump: (17:46) 
They called me, they said, the job you're doing ... Here's the bad part. When you do testing to that extent, you're going to find more people, you're going to find more cases. So I said to my people slow the testing down, please. They test and they test. We had tests and people don't know what's going on. We got tests, we got another one over here. The young man's 10-years-old. He's got the sniffles. He'll recover in about 15 minutes. That's a case, add him to it. That's okay. That's a case. I was actually with a very nice man, very good man, even though he's very liberal, the Governor of New Jersey, right? We know him? Now listen, he said to me, something that's amazing. New Jersey was very heavily hit, very hard hit, thousands of people. He said with thousands of people that died, thousands of people, there was only one person that died under the age of 18 . Would you believe that? Which tells me one thing, that kids are much stronger than us.

Donald Trump: (19:04)

When you see a little kid running around say, "Boy, oh, boy, do you have a great immune system? How about a piece of your immune system?" They don't even know about this. Let's open the schools, please. Open the schools. Open the schools. We got to get them open. In the fall, we got to get them open. The unhinged left wing mob is trying to vandalize our history, desecrate our monuments, our beautiful monuments. Tear down our statues and punish, cancel and persecute anyone who does not conform to their demands for absolute and total control. We're not conforming, that's why we're here, actually. This cruel campaign of censorship and exclusion violates everything we hold dear as Americans. They want to demolish our heritage so they can impose their new oppressive regime in its place. They want to defund and dissolve our police departments, think of that.

Donald Trump: (20:32)

And I heard it for the first time two weeks ago, I said, "Well, that one, I mean, they're only kidding." I said, "They're only, they're not." Minneapolis, you what's going on. They're not kidding. They got a lot of problems. They'll have a lot of problems. Hey, it's 1:00 o'clock in the morning and a very tough, I've used the word on occasion, hombre, a very tough hombre is breaking into the window of a young woman whose husband is away as a traveling salesman or whatever he may do. And you call 911 and they say, "I'm sorry, this number's no longer working." By the way, you have many cases like that, many, many, many. Whether it's a young woman, an old woman, a young man or an old man and you're sleeping. So what are you going to do, right? So they want to defund. They really do, this as a serious movement. And in Minneapolis, the council's already passed it. In Seattle, you see what's going on there, it's even worse, okay. These people are stone cold crazy. They're crazy.

Donald Trump: (21:55)

So if you want to save your [inaudible 00:21:57], you want to say that beautiful heritage of ours, we have a great heritage. We're a great country. You are so lucky I'm president, that's all I can tell you.

audience: (22:19) USA! USA! USA! USA!

Donald Trump: (22:40)

People have come up to me, say, "How do you take it?" I say, "Do I have a choice? Do I have a choice?" We deal with a lot of bad people, but we're winning. And every once in a while, I'll have one of these days where I'm hit left and right, left and right, like even this great event. If you could have seen outside or if you could have heard the reports, the reports, "Oh, it's COVID." It's this again. By the way, it's a disease without question, has more names than any disease in history. I can name, "Kung flu." I can name, 19 different versions of names. Many call it a virus, which it is. Many call it a flu, what difference? I think we have 19 or 20 versions of the name. But they say to me, "Where do you get the energy?" I say, "I don't have a choice. I don't have a choice." It was interesting, to show you how fake they are, you might've seen it. So last week they called me and they say, "Sir, West Point, West Point, we're ready." I said, "Oh, that's right. I have to make the commencement speech at West Point."

Donald Trump: (23:59)

You know, they delayed it for six weeks because of COVID. So they delayed it and I went there. 1,106 cadets were graduated and beautiful. Beautiful [inaudible 00:00:24:14]. Just to show you how bad the fake news is, so they say to me, "Sir, we're ready to go." I say, "Let's go." This is after saying hello to a lot of cadets, inspecting little areas of a building, that was very exciting. Actually, it's beautiful, very old. Studied a lot of our great generals, some of our presidents that went there. West Point is beautiful, right on the Hudson River. But after an hour, the general that runs it is a fantastic guy. After an hour, we land, we do some more inspections and they say, "Sir, are you ready? Yes, I am." So we walked like the equivalent of about three blocks, which is fine. We go onstage, which is fine. They make 
speeches, then I make a speech that lasted a long time. I don't know, maybe 45 minutes, maybe longer, I don't know but a long time. The sun is pouring down on me, okay.

Donald Trump: $(25: 12)$

But they said to me before the speech, "Sir, would you like to salute each cadet, each single cadet? Or maybe there'll be in groups of two. Would you like to salute? Like this? Yes." Like this, almost 600 times. You know what that is? 600 times. Thank God they were in twos because let me tell you, you do that 600 times, you go home and you say it's like a workout without a weight, right? 600 times. So I did that. Then the incredible helicopters, brand new gorgeous helicopters, the Apaches and the other new ones that we just bought.

Donald Trump: (26:03)

Helicopters, the Apaches and the other new ones that we just bought. So they fly over and the kids throw the hats in the air, it's beautiful, it really is. It was a beautiful day and we're all finished. I was on the stage for hours, hours, sun, I came home, I had a nice tan, meaning I had a nice sunburn. The sun's [inaudible 00:26:30] like that, but I make this speech. I salute for probably an hour and a half, maybe more, but around that. Watch. If I'm off by two minutes they'll say, "He exaggerated. It was only an hour and 25 minutes. He exaggerated, he lied, he lied, he's a liar." These people are sick, the fake news.

Donald Trump: (26:59)

So then I finish saluting my final salute, I said, "Thank goodness. Thank you very much." Think of it. So essentially almost 600 times. Now the general says, "Sir, are you ready?" I said, "I'm ready General, where are we going now?" You have to understand I left early in the morning to get there. Now it's sort of late in the afternoon. A lot of these fakers were with us. So they know. He said, " Sir, we can now leave the stage." I said, "Great general, let's go, I'll follow you," and he goes like this, "Right here, sir," and I walked off. The stage was higher than this one and the ramp was probably 10 yards long. I say, "General." Now you got to understand, I have the whole corps of cadets looking at me and I want them to love their president, I did this big thing. I love them, I love them. They're incredible, and they do. I said, "General, I've got myself a problem, general." Because I'm wearing leather bottom shoes which is good if you're walking on flat surfaces. It's not good for ramps and if I fall down, look at all those press back there, look at them. This was a steel ramp, you all saw it because everybody saw it. This was a steel ramp. It had no handrail, it was like an ice skating rink, and I said, "General, I have a problem," and he didn't understand that at first. I said, "There's no way." He understood, I just saluted almost 600 times. I just made a big speech. I sat for other speeches. I'm being baked. I'm being baked like a cake. I said, "General, there's no way I can make it down that ramp without falling on my ass, General. I have no railing."

Donald Trump: (29:27)

It's true. So I said, "Is there like something else around?" "Sir, the ramp is ready to go." "Grab me sir, grab me." I didn't really want to grab him. You know why? Because I said, "That will be a story too." So now I have a choice. I can stay up there for another couple of hours and wait till I'm rescued or I can go down this really steep, really, really, really ... It's an ice skating rink, it's brutal. So I said, "General, get ready because I may grab you so fast." Because I can't fall with the fake news watching. If I fall, if I fall, I remember when President Ford fell out of the plane, do you remember? I remember when another president, nice man, threw up in Japan, and they did slow motion replays. It's true, right? "I don't want that, general." Now he's standing there, big strong guy, and he's got these shoes but they're loaded with rubber on the bottom because I looked, the first thing I did, I looked at his shoes. Then I looked at mine. Very, very slippery. So I end up saying, "Okay, general, let's go. I will only grab you if I need you. That's not a good story. Falling would be a disaster. It turned out to be worse than anything, I would have been better off if I fell and slid down the damn ramp. Right? So what happens is I start the journey, inch by inch, right? I was really bent over too. I didn't like that. I didn't like this picture. This picture I'm sure will be an ad by the fakers. So I was bent over, right? Bent over like this. Then we finally reached almost the end and the fake news, the most dishonest human beings, they cut it off. You know why? Because when I was 10 feet short, I said, "General, I'm sorry," and I ran down the rest, right? I looked very handsome. That was the only good. I wouldn't want to run down the whole thing because the fall there would be definitely bad. So I took these little steps, I ran down the last 10 , and by the way their tape, take a look. In almost every instance, it ends just before I run, and they said, "Here was the number one trending story."

Donald Trump: (32:43)

I call my wife, I said, "How good was that speech? I thought it was a ..." Hey look, I will tell you when I make good ones and bad ones. Like so far tonight, I'm average, but we're having fun, we're having fun. So far tonight, but I call my wife and I said, "How good was it, darling?" She said, "You're trending number one." I said to our great first lady, 
I said, "Let me ask you a question. Was it that good of a speech that I'm trending number one? Because I felt it was really good." No no, they don't even mention the speech. They mention the fact that you may have Parkinson's disease. It's true. It's true. It's true.

Donald Trump: (33:48)

They say there is something wrong with our president. I'll let you know if there's something wrong, okay? I'll let you know if there's something, I'll tell you what, there's something wrong with Biden, that I could tell you.

Donald Trump: (34:07)

So then my wife said, "Well it wasn't only the ramp. Did you have water?” I said, "Yeah. I was speaking for a long time. I didn't want to drink it, but I wanted to wet my lips a little bit." You're drinking, you're working hard up there with the sun pouring down on you. I love this location, the sun's like this. This way they save on lighting, right? That's why they did it probably. So what happens is I said, "What does it have to do with water?" They said, "You couldn't lift your hand up to your mouth with water." I said, "I just saluted 600 times like this, and this was before I saluted, so what's the problem?" She said, "Well I know what you did. You had on a very good red tie that's sort of expensive." It's silk because they look better. They have a better sheen to them. And I don't want to get water on the tie, and I don't want to drink much, so I lift it up, the water.

Donald Trump: (35:15)

I see we have a little glass of water. Where the hell did this water come from? Where did it come from? I look down at my tie because I've done it. I've taken water and it spills down onto your tie, doesn't look good for a long time and frankly, the tie is never the same. So I put it up to my lip and then I say, "[inaudible 00:35:36]", and they gave me another disease. They gave me another disease. Anyway, that's a long story, but here's the story. I have lived with more the ramp than the water but I have lived with the ramp and the water since I left West Point. Not one media group said I made a good speech or I made a great speech, but the kids loved it because they broke their barrier which wasn't good in terms of COVID but they broke their barrier and they wanted to shake hands, they wanted to ... I don't want to tell anybody, but there were a couple of kids, they put out their hand, I actually shook their hand, okay? I actually shook them. Because they were excited. They were excited. They were with their president. They were excited. The most beautiful young people. Men, women, the most beautiful young people you've ever seen. So think of how you feel if you're me. I go there, how did I do? "Sir, that was a great speech." You know all my people, "Sir, that was one of your best, that was great." I said, "That's great, I agree, it was a good speech. I like that speech." They don't mention the speech but they have been going down this ramp [inaudible 00:37:36]. It's so unfair. It really is. So unfair. They are among the most dishonest people anywhere on earth. They're bad people. Bad people.

Donald Trump: (37:54)

Okay, that's enough of that. I wanted to tell that story. Does everybody understand that story? The left-wing anarchists tore down a statue of Thomas Jefferson. Now we're getting into the real stuff. They decapitated a statue of Christopher Columbus, except in New York when the Italians surrounded it. They didn't have too much of a chance. Those Italians, I love the Italians. They heard they were going to rip down their beautiful Christopher Columbus and all of a sudden they circle that thing. They didn't do too well in hurting Christopher, did they? Thank you to our Italian population, we're very proud of you, right? Two days ago, leftist radicals in Portland, Oregon ripped down a statue of George Washington and wrapped it in an American flag and set the American flag on fire. Democrat, all Democrat. Everything I tell you is Democrat and you know we ought to do something, Mr. Senators, we have two great senators, we ought to come up with legislation that if you burn the American flag, you go to jail for one year. One year. Jim and James. Jim and James. We ought to do it. You know they talk about freedom of speech and I'm a big believer in freedom of speech, but that's desecration, that's a terrible thing they do. We used to have things, we don't have them anymore because we want to be so open, so everything, and look what happens? We should have legislation that if somebody wants to burn the American flag and stomp on it or just burn it, they go to jail for one year, okay? In Seattle the Democrat mayor and the Democrat city council have surrendered control of six city blocks to an anarchist ... Now these are anarchists, these are not protestors. You listen to the fake news, they say, "Oh, the protesters were lovely." Could you imagine if people just even slightly to the right tried to take over Seattle? They'd have machine guns out to get them, but these people can take over the city, look at what they've done to businesspeople that have spent years and years building their business, and now they're wiped out. Take it away. Governor Inslee ought to get his act together, get in there, I'll help you, I'll do whatever you want. I'm waiting for a call, I would love to do it. I would love to do it, it'll take less than an hour and it'll all be over with and you'll have your city back. 


\section{Donald Trump: (41:14)}

Yet Biden remains silent in his basement in the face of this brutal assault on our nation and the values of our nation. Joe Biden has surrendered to his party and to the left-wing mob. He has no control. Does anybody honestly think he controls these radial maniacs? You know what he says to his wife when he's not confusing her with his sister? "Get me the hell out of there. These people are crazy." That's what he says. He has absolutely no control. You know a lot of times I'll make like a speech and I'll have this beautiful paragraph come out criticizing every little aspect of the speech, beautiful, brilliant, but Joe didn't ... It'll say, "A comment from Joe Biden," but he didn't say it. Professional people, great students in English lit, people that are very smart say it. Joe Biden said, and they'll go into this highly complex paragraph, beautifully worded and I say, "Joe didn’t say that. Joe doesn’t even understand it."

Donald Trump: (42:35)

If Biden is elected, he will surrender your country to these mobsters $100 \%$. Your $401(\mathrm{k}) \mathrm{s}$, by the way, look at how we're doing in the stock market. Just set another record with NASDAQ. NASDAQ. Your 401(k)s and money itself will be worthless. Your 401(k)s are doing very well unless I don't want to say ... If you were stupid I'd say, "Don't sell. Don't sell. It went down." But we got it back up, and now NASDAQ, think of it. NASDAQ just set a record and I think you're going to see a lot of records, and next year, if we don't do anything stupid on November 3, you are going to have the greatest economic year we've ever had. That will be next year. If the Democrats gain power, than the rioters will be in charge and no one will be safe and no one will have control. Joe Biden is not the leader of his party. Joe Biden is a helpless puppet of the radical left, and he's not radical left. I don't think he knows what he is anymore, but he was never radical left, but he's controlled by the radical left, and now he's really controlled. His campaign staff even donated a lot of money to bail out rioters, looters and arsonists who ravaged Minneapolis. They bailed them out, they put up a lot of money to bail them out, the rioters, the looters and they were, they were the arsonists. They'll say, "Oh, it's terrible what he says about the people of our nation." Maybe some of them aren't even from our nation. The leftists try to do everything they can to stop us. Every hour of every day, including even violence and mayhem, they'll do anything they can to stop us. Look what happened tonight. Look at what happened tonight. Law enforcement said, "Sir, they can't be outside. It's too dangerous." We had a bunch of maniacs come and sort of attack our city. The mayor and the governor did a great job, but they were very violent people. Our people are not nearly as violent, but if they ever were, it would be a terrible, terrible day for the other side. Because I know our people. I know our people, but we will never submit to their threats and we will never let them destroy our nation. What they did tonight, I saw it on television coming in on Air Force One. One thing about Air Force One, we got plenty of televisions. We have televisions in closets. You open up the closet, got a television. We got a lot of televisions. It's a great plane. Great everything. By the way, we ordered new ones. No president wanted to do it. They thought it was luxurious [inaudible 00:45:44] wait a minute, Air Force One is 31 years old. People don't realize that. So I said, they gave me a charge, very early in my administration like how about the first week? "Sir, would you sign for this plane?" Now it's actually two planes. "Would you sign for this plane? Air Force One?" I said, "How old is the original or the one we have now?" "Sir, it's 31, 32 years." I'd see people coming in from foreign lands that can't compete with us, rich countries but they can't compete with the ... They have a brand new beautiful 747-800, and I say, "Wait a minute. That country has new and we have a 31-year, so somebody had to do ..."

Donald Trump: (46:29)

So the deal was made and it was made for a lot of money. I think it was $\$ 5.7$ or $\$ 5.6$ billion. Now in all fairness, it's two planes and there's a lot of stuff in those planes I won't talk to you about. So I told Boeing, the head of Boeing, they said, "Sir, please, we'd like to get started on the planes," I said, "I do too, but I'm not paying \$5.6 billion, and I'm not paying $\$ 4.6$ billion." I said, "It has to have a three on the front of it." That's a hell of a lot of money too, but it is a rather complex situation. They said, "No way." No way. This was before Boeing had problems by the way, but Boeing is coming back. They're coming back. Greatest company of the world and that's their big problem. It had a couple of problems that didn't work out. That was terrible, but the greatest. I think before that, it was the greatest company in the world. It made up a quarter, one quarter of a point, of our GDP. Think how big that is, one company. It was an unbelievable machine and then they made a plane and they did some foolish things and a terrible thing happened and all of a sudden they've gone through hell but you know what? They're coming back, we're ready to help them if they need it but they're coming back in the coming [inaudible 00:47:56]. This was the Boeing before that and they were riding high, like I was before this thing came in, but we're still riding high because you know what? On November 3 we're going to win. We're going to win. So they came in and they came in and they said, "No no no, we want $\$ 5.6$ billion, whatever it was." Whatever it was, if I'm a little bit off they'll go crazy. Whatever, but it was a lot. \$5.6 billion. Nope, got to have a three. Got to have a three, call me up. Nope, cancel the contract. I said, "Cancel the contract. I want 
it canceled." I said, "General, can you cancel the contract?" He said, "Yes sir, I'm very proud of it." "Oh good. Cancel it." "Okay sir." "By the way, to cancel it, do you have to pay anything?" "Yes sir. We have a cancellation fee sir." "How much is it, general?" "\$250 million." I said, "What?" "Sir, we made a good deal. \$250 million to kill." "You mean if we don't buy the plane we have to hand them $\$ 250$ million." That's not good, right? Look at these two guys, they're looking.

Donald Trump: (49:12)

By the way, that's like a good story compared to some I could tell you, like with aircraft carriers. So they said, "\$250 million?" Or I always say this, or around that number, because if I'm off by a little bit, they say, "Oh, he exaggerates." I look at numbers all day long. That's what I look at for years now, for my whole life when you think of it. \$250 million cancellation fee, sir. He was very proud of himself. What a great ... I say, "General. Don't cancel. Don't cancel. Just tell them I don't want the planes. Don't put anything in writing, don't put it in writing, general." "Why sir?" "Because I don't want to pay 250." True. You hear that Jim? Jim Inhofe, he's great. You hear that Jim? You know that story. He does a great job.

Donald Trump: (50:03)

So here's what happened, the bottom line. Boeing says, "No way, no way, no way." The next week they say, "No way we're doing it." The next week they said, "How about \$5 billion?" I said, "No way. No way." The next week they said, "\$4.8." I said, "Nope. It's got to have a 3 at the front of it. Don’t you understand, you dumb son of a bitch? Don’t you understand?" I turned out to be right. Turned out to be right. Nobody gets that. Nope. Got to have a three. Next day, they come back, "\$4.5 is our best offer." "Nope. I'm not doing it. I'm not doing it. Come back when you're ready." A month goes by, another month, they never heard about it, they never heard from me, they thought I was serious, I was, and they came back at $\$ 4$ billion.

Donald Trump: (51:10)

That's a lot of money but I save like a billion six or a billion seven. Nobody wants to talk about it. Nobody wants to talk about it. When I get foreign nations to pay us billions and billions of dollars, nobody wants to talk about that. When I take soldiers out of countries because they're not treating us properly, Germany is an example. I mean I have a German heritage like some of you. I said, "Let's get it down from $\$ 50,000.00$ to $\$ 25,000.00$ because they're delinquent. For many years they're delinquent. They haven't been paying what they're supposed to be paying. They're paying $1 \%$ instead of $2 \%$ and $2 \%$ is a very low number," and they say, "Yes, we think by

Donald Trump: (52:02)

And they say, yes, we think by 2030, maybe 2032, we could get current. I said, “No, Angela, please. Don't say that Angela. It's true. You know who I'm talking about. By the way, very nice woman. Very good negotiator. I said, "Angela, that's a long time," this was in 2019. She said 2032. I said, "No Angela, that's not working." But I said, because now they want to get cared, but I said, "Well, what about the last 25 years? All the money you owe us?" Everybody forgot about that. They forget about all the money that wasn't paid. I said, "What about the trillion dollars that you really owe?" So we're negotiating let's see, but in the meantime, we're reducing our troops.

Donald Trump: (52:48)

Remember this, we're supposed to protect Germany from Russia, but Germany is paying Russia, billions of dollars for energy coming from a brand new pipeline. So they pay the country we're supposed to protect them from, they pay billions of dollars to that country. We're supposed to protect them. Excuse me, how does that work? And the great thing is with Jim Inhofe and with James Lankford, likewise, they just said they love you James. When they hear it, they get it. A lot of people don't get it. They get it. We cannot continue to be ripped off. We're ripped off by so many countries and we're stopping it. And that means that a lot of people don't want me here. They don't want me. There are a lot of people that don't want me. They don't sell a lot of bombs when we're not dropping bombs on people. You know that, right? It's called the military industrial complex.

Donald Trump: (54:04)

When rioting and looting broke out in our nation's Capitol, I very quickly deployed the National Guard. I said, "Get them in." After watching for an evening or two, we stopped the violence and restored peace and order to the streets. And last night that had a little breakout. Again, they ripped down a statue that was 110 years old, beautiful piece of art in front of the police precinct with our radical left mayor watching on television. We're not happy. That's going to be very expensive for DC. They're always looking for money. "We need more money. We always need more money." And then they don't do the proper job. So it's not going to be good for Mayor Bowser, Mayor Bowser there. 


\section{Donald Trump: (54:54)}

They were heading over to the Jefferson Memorial recently and they wanted to do damage to our great, beautiful Jefferson Memorial. Not going to happen. Don't worry about it. We have it surrounded with very strong people. The choice in 220 is very simple. Do you want to bow before the left wing mob? Or do you want to stand up tall and proud as Americans. And explain this to the NFL. I like the NFL. I like Roger Goodell, but I didn't like what he said a week ago. I said, "Where did that come from in the middle of the summer? Nobody's even asking?" We will never kneel to our national anthem or our great American flag. We will stand proud and we will stand tall. I thought we won that battle with the NFL. The stadiums were emptying out. Did you see those stadiums? It took them a long time to get you back. A lot of people didn't like that. A lot of people that you wouldn't even think would care that much. I've had people that I said, "These are super left liberals and they didn't like it."

Donald Trump: (56:26)

Joe Biden and the Democrats want to prosecute Americans for going to church, but not for burning a church. They believe you can riot, vandalize and destroy, but you cannot attend a peaceful pro-America rally. They want to punish your thought, but not their violent crimes. They want to abolish bail, abolish and open up your borders. They want open borders, let everyone, and by the way, we're doing so well. We have a record this month on the borders. Nobody's coming in. Very few people. And they want to abolish ICE, our great people from ICE who send the roughest toughest, meanest people that you've ever seen or ever heard.

Donald Trump: (57:27)

Generally speaking, when they have lots of tattoos on their face, they're not looking to do you much help. ICE, they're rough guys. they're great Americans, but they'll walk into, they caught them in a pack. They'll walk into a pack of tough MS-13 gang members. And we shouldn't say this, it's not nice. They want us to negotiate. They start swinging. And the other such way, everybody's swinging, at the end, they carry them back and they throw them into the paddy wagon. They're great. And these people want to get rid of ICE. They get rid of murderers. They get rid of rapists. They get rid of the worst scum on earth.

Donald Trump: (58:13)

And when I called them animals, I said, “They're animals." And Nancy Pelosi, they cut up a young woman. They cut up a young woman and her friend, cut them up with a knife because it was more painful. Dead. Cut them up with a knife because it's more painful. It takes longer than shooting a gun. They cut them up. I said, "These are animals." And Nancy Pelosi said, "These are human beings. They're not animals." If I lose an election over that, you know what? This country is in big trouble. They want to disarm law, abiding citizens and dismantle our police forces while freeing vicious MS-13 gang members. In Joe Biden's America, rioters, looters, and criminal aliens have more rights than law abiding citizens. And that's true. In my administration, we defend American citizens and we deport MS-13 members or put them in jail if we have to. The chaos you're seeing in our democratic run cities, these are all run by the Democrats, is what will happen in every city and community and America, and much, much worse if we don't keep them out. We have to do this. We have to go to the polls on November 3rd and the rest of you know what to do. You know what to do. Got to keep the White House. Joe Biden's record can be summed up as four decades of betrayal, calamity, and failure. He never did anything. He was a Senator. He was a Vice President. He was before that something. You know what's great? President. Trump was tough on this or he was tough. They complained, never did anything about it. He's been there for 43 years or 47 years. He never did anything about it. Biden's supported every globalist attack on the American worker let's make every country of the world rich but ourselves, including NAFTA, the disaster of NAFTA. He wanted to go and TPP would have ruined our automobile industry.

Donald Trump: (01:00:47)

Korea, I renegotiated the deal. I took a horrible deal. That was a Hillary Clinton special. That was a Hillary Clinton special. She said, "We have to make this deal with South Korea. It's going to mean 250,000 jobs." And she was right for South Korea, 250,000. And China's entry into the World Trade Organization was supported by sleepy Joe Biden. That was one of the worst deals economically in the history of our country. When China joined the World Trade Organization, they were flat line for decades. They became like a rocket ship. He voted for the war in Iraq. He voted for mass amnesty for illegal aliens. He supports sanctuary cities and now Biden wants to end immigration enforcement and he wants to require you to provide free healthcare for millions and millions of illegal aliens. 
Donald Trump: (01:01:53)

When I took early and decisive action to ban travel from China and protect Americans from the virus. And as I said, Joe Biden, opposed my decision and called it hysteria, xenophobia. He doesn't know what the word means, xenophobia and fear-mongering. And then he apologized a month later. He said he was wrong, but he didn't say it. And they didn't cover it. They didn't cover it. On one of the single most important policy decisions of our lifetime, Joe Biden sided with China over America, that's closing the border. He thought it was a terrible thing. Remember, this was in January. That's early, real, early, the end of January. He thought it was a terrible thing. When we close the border. Too many people that were badly infected with COVID.

Donald Trump: (01:02:49)

When the chips are down, Biden will always cave to the radical left. He'll always bow to the angry mob and he will never protect you or your family and you know that. Joe Biden will always let you down. That's been his history. At my direction early this year, the heroes of the U.S. military took out the world's top terrorist, the savage killer leader of ISIS al-Baghdadi and the number one terrorist, anywhere in the world, Qasem Soleimani. We took them out. Joe Biden opposed killing Soleimani. He was vehemently... We killed this number one, terrorist. He didn't like it. You know why he didn't like it? Because he thought it would be good politically, that didn't work out too well. Just as he opposed the raid that killed Osama bin Laden. He opposed it, you know that. Biden is always on the wrong side of history, as said by people that are with him and worked with him. He never made a correct foreign policy decision. Biden is a puppet for China. Son walked out with 1.5 billion. I think it's a little bit...

Donald Trump: (01:04:12)

Allowing them to rip off America for many years. Now they're paying us billions and billions of dollars. We give a lot of it to our farmers. We have plenty leftover. China is not exactly happy with me. They pay us billions and billions of dollars. And they targeted our great farmers. And I took the money that they targeted, I took that money and I gave it to the farmers. So they were even so they're okay. Are you okay? Come, Doctor, please. Doctor. Thank you. These people some of the people are waiting for five days, especially in this location. You take your time, darling, take your time.

Speaker 1: (01:05:06)

God bless you, Trump.

Donald Trump: (01:05:06)

Thank you very much. Take your time. Doctor, thank you, doctor. Some people wait for four or five days. That's incredible. He never did anything against China, Joe Biden. And that's why they desperately want him to win. They want him to win so badly. Iran wants him to win so badly. Let me tell you, I'm going to make a very fast deal. The best deal you've ever seen. I've already made one with China, but I can make even more. They want me to lose because they will own the United States if I lose. Iran. President Obama gave them $\$ 150$ billion for nothing.

Donald Trump: (01:06:26)

And almost more incredible, he gave him 1.8 billion in green cash. Beautiful cash. And now they're not doing so well, are they? They're not doing so well. Someday, we're going to get credit for this, someday, but they are waiting. Iran wants to make a deal so badly. But they're told by Carey and all these other, they shouldn't the Logan Act, but they're told Carey and all these people, "Wait, because if Trump loses you'll own America, you're going to own it." They'll say you own it. So I don't mind. I told them we can wait, but when I win, you're going to pay a much higher price than if you made a deal [inaudible 01:07:12].

Donald Trump: (01:07:08)

I told them. And look what happened to Biden in Ukraine where his son's paid $\$ 83,000$ a month. And he was jobless. Give me a break. $\$ 83,000$ a month. More than anybody. If Joe Biden were to become president an emboldened left, will launch a full scale assault on American life. You know that. They'll expel anyone who disagrees with them. Look what happens when you disagree. You use a term that's perfect and they're not happy with it. They call you a racist. They call you a horrible person. They want to crush religious liberty. They don't want religion. Silence religious believers, indoctrinate your children with hateful and vicious lies about our country, subsidize late term abortion and after birth execution. 


\section{Donald Trump: (01:08:13)}

They want to take away your guns through the repeal of your Second Amendment, as sure as you're sitting there. In fact, he even put the big gun grabber, Beto O'Rourke, who made a fool out of himself when he ran for president. They put him in charge of guns. Lots of luck on your Second Amendment. Just remember I said, and hopefully you won't have to think back about it too much, because it won't matter. Hopefully it won't matter. No, Beto O'Rourke who wants to give up guns is in charge of the second amendment. The Dems will also eliminate private health insurance, ban fracking, that's not good, and American energy will be in a position of weakness like it's never been before. And that's after we built the greatest energy country anywhere in the world by far.

Donald Trump: (01:09:11)

And they want to appoint Supreme Court justices who will utterly obliterate your Constitution. And you now see how important the Supreme Court is. Think if we didn't have two justices, that I think have been very, very, very good, but think how important it is. Think how important it is. And we still, I guess it's a, I don't know if it's an equal court, it's almost like we're a minority court, right? It's almost like we're a minority court. The recent Supreme Court cases prove that if Joe Biden is elected, he will stack the court with extremists, the forgotten men and women, together with everyone else. We'll lose everything. The forgotten men and women, I campaigned on the forgotten. These are great people. These are substantial people. These are the elite. By the way, you're the elite. They're not the elite. You're the elite.

Donald Trump: (01:10:13)

Somebody two days ago said, "Sir, the elite are really working hard on trying to destroy you." I said, "Yeah, why do you call them the elite," I said, "why?" "Well, they're not elite." I look better than them. Much more handsome. Got better hair than they do. I got nicer properties. I got nicer houses. I got nicer apartments. I got nicer everything. I ran for politics once, just once in my life. And I became President of the United States. And hopefully if you get out and vote, we'll do it one more time. We won't even toy with them about three or four more times. We won't. We'll do it one more time. We'll be two for two. And our country will never, ever be stronger.

Donald Trump: (01:11:27)

But I'll be soon announcing a new list of exceptional candidates for the United States Supreme Court. And I'll choose only from that list. A hundred percent, probably 25 incredible people, any one of which could be a great justice, any one of which. And I did it last time and people loved when I did it. And I'll only pick from that list. Biden can't release his list because the names would be too extreme, too radical. They wouldn't be acceptable, but they will be very radical people. People don't understand, but we actually won on DACA yesterday. We actually won because they basically said, "You won, but you have to come back and redo it." It's almost like, "Gee, come on back, your paperwork was no good." But we're going to be refiling, but don't let it get you. Everything's going to work out really good. Everything's going to work out good.

Donald Trump: (01:12:28)

It was a great, it was great. I mean, would have been nice if we won. And Everybody said, "Oh, you're going to win DACA. You're going to win DACA. That's easy. You got to win DACA. That's easy.” They all said it. And they came back and they said, "We don't like what you did with your paperwork," essentially. So we're re-filing it. Most people would say we lost. We didn't lose. We're going to refile it. And everything is going to work out for the young people. Most of whom aren't so young anymore, by the way. But we're going to work it out for everybody. Biden is fully controlled by the fringe of his party. He is their pawn. He doesn't even know where the hell he is. Let's face it. He installed socialist Alexandria Ocasio-Cortez.

Donald Trump: (01:13:19)

To be in charge of his environmental policy and his energy. Energy, you can forget petroleum. How does Oklahoma feel about being petroleum free? Not good, right? Our country will have no energy. Our country will have nothing. Oklahoma, Texas, North Dakota, and many others will all be out of business. I don't think that's going to work out too well, but she's actually in charge of environmental policy. And you know what that means. She doesn't even want to win. She doesn't want those bird killing machines that go round and round. You want to see a lot of birds that are dead? Go under a windmill sometime. She wants us to go back to the stone ages because she's got no sense, no credentials. She's got a little charisma, not much, but she doesn't have a clue. You know it. But she's in charge of the environment. No airplanes. We can forget Boeing, I guess, come to think of it. We talked about Boeing. We could forget Boeing. Let's cancel those brand new Air Force Ones. 
Donald Trump: (01:14:32)

Likewise, Representative Ilhan Omar is going to be very much involved in a Biden government. They will put this hate filled America, bashing socialist, front and center in deciding the fate of your family and deciding the fate of your country. I don't think she would like to make the government of our country just like the country from where she came, Somalia. No government, no safety, no police, no nothing. Just anarchy. And now she's telling us how to run our country. No thank you. And I think we're going to have a big victory in the state of Minnesota, because they've had it. They've had it.

Donald Trump: (01:15:40)

Biden is a very willing Trojan horse for socialism. When Biden first ran for president over 33 years ago, remember I used to call him $1 \%$ Joe, he never got more than $1 \%$ until Obama took him off the trash heap. But he blatantly copied the speech of a British politician, even ripping off the man's personal biography and family history and claiming it was his own. He forgot to say he was born in America. Joe Biden is a shameless hypocrite. Since 2003, he has delivered fawning eulogies to the funeral. And at those funerals of three leading supporters of segregation, including a former member of the KKK, and yet Biden is now smearing as racist, tens of millions of people like yourselves. Decent, hardworking Americans who he's never met. And he frankly probably doesn't want to meet. America should not take lectures on racial justice from Joe Biden. Sleepy Joe. A man who praised and partnered with segregationists, shift millions of black American jobs overseas, and everyone else's jobs too by the way. If I didn't come along, we're building auto plants, we're building everything. And there's never been a comeback like we're making right now. Never been.

Donald Trump: (01:17:19)

He hollowed out our middle class, including our black middle class with open borders. Trapped young children in failing government schools, built cages. Those cages were built by Obama and Biden. Look it up, 2014. And the fake news doesn't wanted to... Remember the picture of the cage? A cage for children. Remember the picture of the cage. And they said President Trump. And then they realized that was at a newspaper, 2014, the same... Built by Obama and Biden, the cages. And they don't-

Donald Trump: (01:18:03)

And they don't want to report the way it is. They know the way it is. They're not stupid. They sent young boys to fight in Iraq while the inner cities crumble, helped the big banks while hammering community leaders, and made our cities less safe and secure for all. They've done a terrible job and they shouldn't be awarded. They should not get rewarded with an election victory on November 3rd, that shouldn't happen. It'll destroy this country. Our country will be destroyed. We've all worked too hard. They don't know what the hell they're doing. Some do actually, but in a very sinister way. Virtually every policy that has hurt black Americans for half a century, Joe Biden has supported or enacted. I've done more for the black community in four years than Joe Biden has done in 47 years.

Donald Trump: (01:19:10)

Racial justice begins with Joe Biden's retirement from public life. We are joined tonight by many outstanding Republican leaders. These are great people. We have two of our most distinguished, hardworking, wonderful friends, senators. They do a great job. Senator Jim Inhofe and James Lankford, please stand up. Two very respected, I will tell you, two very respected people in Washington. They're respected by everybody. They do some job, and I'd have you come up, but you can relax. I will say this. Jim is running on November 3rd, Jim Inhofe. He's running on November 3rd. I don't even know. Does he... Hey, James? Does he have any competition? Is somebody actually running against... There's no competition that he's got. I know he's got James' support. He's got my support. I give him 100\% endorsement. Jim Inhofe. I'd give it to James too, but he's not running this time. Thank you. Jim, great job. Thank you very much. What a great Senator he is.

Donald Trump: (01:20:36)

Also here is a man who's respected by so many. He's a little bit right of the people we've been talking about tonight. Senator Tom Cotton of the great state of Arkansas. Thank you, Tom. They like you people.

Speaker 2: (01:21:05)

Patriot. 


\section{Donald Trump: (01:21:06)}

Thank you, Tom. Great job you're doing. We're glad to be joined as well by a man that I've gotten to know. He's done an incredible job with COVID and with everything else he touches, Governor Kevin Stitt. Thank you both. Thank you both for being here. Thank you. Lieutenant Governor Matt Pinnell. Thanks, Matt. Thanks, Matt. And Representatives Frank Lucas, Tom Cole. He's been here for a little while. He's done an incredible job. Markwayne Mullin, you don't want to fight with him. I want to put him and Jim Jordan in a match together, I want to. Kevin Hern, great job today, Kevin. The great Jim Jordan, Jim Jordan. Elise Stefanik. Lee Zeldin. Tom Emmer. Tom, thank you. These are warriors, folks. These are great warriors. During the fake impeachment trial, I'll tell you what. There was nobody that could have done the job they've done. That includes the Senate and the House. These people are incredible.

Donald Trump: (01:22:56)

David Kustoff. David. A great friend of mine. Debbie Lesko, Arizona. Great job, Debbie. Great job. And a man who's got very good genes, Greg Pence. Thank you all. Great job. They're great... They are, they're warriors. I'll tell you what. Not every person is, but this group is, and we have a lot of them in Washington, and we'll send Jim Inhofe back, and we'll send all of them. You'll send every one of them. They have to come back because they have been fighting for us, and they've been fighting for you. And they are just incredible, talented, tough, strong people that love your state a lot. So thank you very much.

Donald Trump: (01:23:56)

So we built the greatest single economy in the world. And then we say not only the world, but actually in the history of the world, and they never even challenged me. So I guess I'm right. We did it. We had the best numbers anybody's ever had. We have the best employment numbers, African American, Hispanic American, Asian American, the best employment numbers in history, the best stock market numbers in history. We were the envy of the world. Everybody would come in to see me, presidents, prime minister, kings, queens, and dictators. Dictators would even come in to say congratulations on the economy. And then the plague came in, and now what we're doing is we're doing it again. And it's going fast. We have to have a lot of it done because people don't quite get it. We're doing record business. It's happening at a level and a speed that nobody can believe.

Donald Trump: (01:24:59)

Two weeks ago, job numbers came in the single biggest number in the history of our country. Last week, retail sales numbers came in, retail sales, the single greatest number in the history of our country. So here's what's going to happen. Here's what's going to happen. They blame a President for anything. When you see looters, even though we put them down, if we didn't stop them, nobody would because the other side will never stop them. But they always blame a President. Here's what's happening. We're going up. We're going up. We're going up. We're going to go up. Then we're going to hit October. We're going to be up. We're going to be way up. We're not going to be where we were, but in many ways, other than all of the horrible, horrible death that was so needlessly caused by a virus that should have been stopped where it originated, which was China.

Donald Trump: (01:26:09)

But we're going to go up, up, up, up August, September, October, and people are going to say, "Man, this guy is doing a good job. He knows what he's doing. I don't believe the fake news anymore." And you're not going to want to lose your 401k's. And you're not going to want to lose all of that wealth that you've accumulated, whether it's real estate wealth or any wealth you can think because it'll all come tumbling down if these people are put in charge. And if they double and triple and quadruple your taxes, it will be a whole different ball game. So I'm not putting any pressure on anybody, but in the end, we're going to have a phenomenal economy. And next year we're going to have a good third quarter, but next year, and I said it before, will be the single greatest year economically that we've ever had, okay?

Donald Trump: (01:27:09)

And if you see that happening, if you see it happening on November 3rd, you don't have the guts to vote against Trump. You, even you, you don't have the guts to vote against Trump. Say, "Wait a minute, darling. My 401k is higher than it was the last time. I don't think I want to take a chance." You're not going to want to do that. The stock market has been the best. Think of this, go back one week and go back 50 days. In that 50 day period, it's the strongest 50 days in the history of the stock market, think of it. And your wife or your husband says, "Darling, I love you so much. You are such a great investor." And all you did is just keep the same crap you had the first time, right? "Darling, I love you so much. You've always been a loser. You've always lost money. But now under President Trump, you're one of the greatest financial minds in our country." And all you did was keep your stock. 


\section{Donald Trump: (01:28:17)}

Now, if you think you're going to run against... Oh, they're going crazy. They want the stock market to go down. Even if it costs them money, they want the stock market to go down even if it costs them money, and they don't even know why. You know what, they're smart and they're vicious, but they don't know why. I'm telling you, they don't know why. What's wrong with having the strongest military brand new in the world, [inaudible 00:10:44]? What's wrong with having these great economic numbers? What's wrong with having to close it down? We saved millions of lives. You know, a lot of people say we should have gone herd, let's go herd. Ask them how are they doing in Brazil. He's a great friend of mine, not good. You heard about Sweden, right? Too much. Ask them how they do it in Sweden. We saved millions of lives, and now it's time to open up, get back to work, okay? Get back to work.

Donald Trump: (01:29:14)

I recently signed groundbreaking criminal justice reform. I secured record and permanent funding for historically black colleges and universities. We slashed regulations and passed massive tax cuts to give black workers a pay raise like they've never, ever gotten before and lift up black owned businesses. And I worked closely with a great senator also, friend of theirs, Senator Tim Scott, South Carolina, to create opportunity zones, which are doing incredibly. And since then countless jobs and $\$ 100$ billion of new investment, not government investment, have poured into 9,000 of our most distressed neighborhoods anywhere in the country. 9,000, never happened before. Tim Scott. Today. I'm also announcing that I have directed Secretary of the Interior David Bernhardt to place the John Hope Franklin Reconciliation Park here in Tulsa on the African American Civil Rights Network. So many of my friends have been asking me to do that. So many of my friends, including these great politicians. So we're going to do that. It'll be done very quickly.

Donald Trump: (01:30:55)

We will forever remember and honor the courageous people who helped build this state and this country. Democrats are stoking division in order to distract from their decades of failure on schools, jobs, housing, justice, and crime. In major city public schools run by Democrats, over two thirds of students are falling behind in reading and math. And I think the numbers are worse than that. But Democrats would rather deny these children the future they deserve than allow them to attend the charter, public, private, religious, or independent schools of their choice. Pro choice, pro choice. Pro choice for schools. It's very popular, but some people it's like a disaster because what it does to certain unions that have a lot of power over the Democrats, even though they know it's wrong.

Donald Trump: (01:31:59)

Republicans believe access to education is a civil right. It's a civil rights. 20 of 20 of the most dangerous cities in America are controlled by Democrats. Think of that, 20 of 20 . And so is nearly every major city with a child poverty rate that's over $30 \%$. They're controlled by Democrats. We can name every one of them. The murder rate in Baltimore and Detroit is higher than El Salvador, Guatemala, or even Afghanistan. How are they doing, the Democrats running those cities? Your whole country will be like that. In 2018 alone, our police arrested nearly 12,000 people for murder and manslaughter, 25,000 people for rape, and nearly 1.5 million for assault, violent assault. The Democrats' push against our police will drive up crime and drive up costs at levels you'd never believe. Thousands of innocent lives will be lost. As President, I will always support the incredible men and women of law enforcement.

Donald Trump: (01:33:29)

A vote for Republicans is a vote for better schools, better jobs, safer families, and stronger communities for all Americans. There is a limit to what we can together achieve with four more years. With your help, we will lift millions of our citizens from welfare to work, dependence to independence, and poverty to prosperity. That's what's happening, that's what's happening. And that was happening at a level that nobody ever thought they'd see, it was happening before this COVID came in. It was happening at a level that nobody believed possible. And then China sent us the plague, thank you very much. We will protect Medicare and Social Security for our great seniors. And we'll always protect patients with pre-existing conditions. Always, always. We will appoint more judges to interpret the Constitution as written. We will end deadly sanctuary cities. We will finish the wall, which has now 212 miles built and beautiful.

Donald Trump: (01:35:06)

212 mile. That's a lot of miles. And let me tell you, you think that was an easy one, that was a tough one. That party was totally unified against building the wall. You know, in the end they gave up, you know what happened? They realized it was a bad issue for them because these open borders. I love when they fight for open borders because anybody that 
wants an open border coming in from rough areas, there's something wrong with those people. So did you notice in the end it was like, "Just leave us alone, build your wall, just leave us alone." I said, "Thank you very much."

Donald Trump: (01:35:49)

And we will elect a Republican Congress to create a fair, safe, sane, and lawful system of immigration that puts American workers first. We will revitalize our cities, and we will build gleaming new roads, bridges, tunnels, and airports all across our land. We will enact new trade deals that result in more products proudly stamped with that beautiful phrase, Made in the USA. It's so beautiful, so beautiful. Made in the USA. That's happening too. We have so many plants coming into Michigan and so many other states. We have car plants coming in would have never come if I wasn't President, would have never come. We will become the world's premier pharmacy, drug store, and medical manufacturer. That's already started. We're bringing it back. We will keep America out of foolish, stupid, ridiculous foreign wars. We will never hesitate to kill America's terrorist enemies.

Donald Trump: (01:37:08)

When I took over, ISIS was all over the place, and I did something that I felt we should do. And we have now obliterated, we have now captured $100 \%$ of the ISIS caliphate. 100, 100. And like our depleted military when I took over, like our empty shelves, medically, when I took over, like all of the things that when I took over, it was a mess, we have done a job. You had to see what ISIS was doing. They were getting bigger, bigger, bigger, bigger, bigger. I came in, smaller, smaller, smaller. "Sir, we've just taken 100\%." We will launch a new age of American ambition in space. And the United States will be the first nation to land on Mars, good program. You saw the beautiful rocket three weeks ago go up, beautiful. We will defend privacy, free thought, free speech, religious liberty, and the right to keep and bear arms. And when you see those lunatics all over the streets, it's damn nice to have arms. Damn nice. Interesting how all of a sudden people understand it, right? You couldn't sell it. Now people understand it. The right to keep and bear arms, we'll protect your second amendment. Above all, we will never stop fighting for the sacred values that bind us together as one America, we will support, protect, and defend the Constitution of the United States. We uphold the principle of equal justice under the law. We believe in the dignity of work and the sanctity of life. We believe that faith and family, not government and bureaucracy are the true American way. We believe that children should be taught to love our country, honor our history, and always salute our great American flag. And we live by the words of our national motto, it will never change, "In God we trust." We stand on the shoulders of American heroes who crossed the oceans, blazed the trails, settled the continent, tamed the wilderness, dug out the Panama Canal, laid down the railroads, revolutionized industries. Won two world wars, defeated fascism and communism, and made America the single greatest nation in the history of the world. And we are making it greater and greater every single day. Proud citizens like you helped build this country, and together we are taking back our country. We are returning the power to you, the American people. With your help, your devotion and your drive, we are going to keep on working, we are going to keep on fighting, and we are going to keep on winning, winning, winning.

Donald Trump: (01:41:26)

We are one movement, one people, one family, and one glorious nation under God. America will soon be thriving, like never before because, ladies and gentlemen of Oklahoma, the best is yet to come. Together we will make America wealthy again, we will make America strong again, we will make America proud again, we will make America safe again, and we will make America great again. Thank you. Thank you, Oklahoma. Thank you.

\section{Copyrights}

Copyright for this article is retained by the author(s), with first publication rights granted to the journal.

This is an open-access article distributed under the terms and conditions of the Creative Commons Attribution license (http://creativecommons.org/licenses/by/4.0/). 